\section{MANOJLOVIĆ ${ }^{1}$ \\ B. OBRADOVIĆ V. NEDOVIĆ \\ I. LESKOŠEK-ČUKALOVIĆ 2 BRANKO BUGARSKI ${ }^{1}$ \\ ${ }^{1}$ Faculty of Technology and Metallurgy, University of Belgrade, Belgrade \\ ${ }^{2}$ Faculty of Agriculture, University of Belgrade, Belgrade}

\title{
ELECTROSTATIC GENERATION OF ALGINATE MICROBEADS LOADED WITH BREWING YEAST
}

Electrostatic droplet generation is a promising technique for production of hydrogel microbeads with immobilized cells and enzymes even at a large scale (Bugarski et al., 2004). It is based on the use of electrostatic forces to disrupt a liquid filament at the capillary/needle tip and form a charged stream of small droplets. Electrostatic potential is applied between the capillary/needle and a collecting bath, inducing a charge at the surface of the polymer solution and resulting in a decrease in surface tension. In this way, a significant reduction of droplet size may be realized as compared to the simple dropping method. Droplets are collected in a hardening solution where the ion exchange takes place, providing gellation and formation of microbeads. In the previous studies, it was shown that microbead size was a function of applied potential, polymer surface tension, needle size and electrode geometry (Bugarski et al., 1994, Poncelet et al., 1999, Nedović et al., 2001). This paper is aimed to further experimentally explore feasibilities of electrostatic droplet generation for the production of uniform hydrogel microbeads and cell immobilization. The effects of suspension flow rate, and alginate and cell concentrations on the bead diameter were investigated.

\section{MATERIALS AND METHODS}

Investigated polymer was medium viscosity alginate A-2033 from Macrocystis pyrifera (Kelp). Polymer solutions of different concentrations in the range $1-2.5 \%$ were prepared by dissolving $\mathrm{Na}$-alginate powder (Sigma, St.Louis, USA) in distilled water. Polymer/cell suspensions were formed by mixing prepared $\mathrm{Na}$-alginate solutions with a suspension of brewing yeast cells at various volume ratios. Spherical droplets were formed by extrusion of the polymer/cell suspension through a blunt stainless still needle using a syringe pump (Razel, Scientific Instruments, Stamford, CT) with a $10 \mathrm{ml}$ plastic syringe. The electrode geometry with a positively charged needle and a grounded hardening solution was applied. Hardening solution was

Author address: V. Manojlović, Faculty of Technology and Metallurgy, University of Belgrade, Belgrade

Paper presented as a poster.
$\mathrm{CaCl}_{2}$ at a concentration of $2 \%$. The potential difference was controlled by a high voltage dc unit (Model 30R, Bertan Associates, Inc., New York) and was kept constant at $7.5 \mathrm{kV}$. Distance between the needle tip (22 gauge) and the hardening solution was $2.5 \mathrm{~cm}$ while the flow rate of polymer solution was varied in the range 3 to $25.2 \mathrm{ml} / \mathrm{min}$.

In the first set of experiments, effects of flow rate on the microbead size were investigated. $\mathrm{Na}$ alginate solution at a concentration of $1 \%$ was extruded at different flow rates in the range 12.7-25.2 $\mathrm{ml} / \mathrm{h}$ while the other parameters were kept constant (electrostatic potential of $7.5 \mathrm{kV}$, electrode distance of $2.5 \mathrm{~cm}$ and 22 gauge needle).

In the second set of experiments, effects of polymer concentration on the microbead size were investigated. Concentrations of $\mathrm{Na}$-alginate were varied in the range $1-2.5 \%$ while the other parameters were kept constant (electrostatic potential of $7.5 \mathrm{kV}$, electrode distance of $2.5 \mathrm{~cm}, 22$ gauge needle and the polymer flow rate of $12.7 \mathrm{ml} / \mathrm{h}$ ).

In addition, a series of experiments were conducted with alginate/yeast suspensions in order to evaluate the effects of cells on the microbead size. The initial cell concentration was varied in the narrow range of $1-4 \times 10^{7}$ cells $/ \mathrm{ml}$ and the concentration of $\mathrm{Na}$ alg inate solution was varied in the range $1-2.5 \%$ while the other parameters were kept constant (electrostatic potential of $7.5 \mathrm{kV}$, electrode distance of $2.5 \mathrm{~cm}, 22$ gauge needle and the polymer flow rate of $12.7 \mathrm{ml} / \mathrm{h}$ ).

Volumetric and cumulative size distributions were determined by laser light scattering using a 2602-LC particle analyzer (Malverine Instruments) according to a lognormal distribution model. The mean bead diameters and standard deviations were calculated from the obtained cumulative distribution curves.

\section{RESULTS AND DISCUSSION}

Results of the first experimental series are presented in Figures 1 and 2. Varying the alginate solution flow rate, while keeping the potential difference and the needle diameter constant, had a moderate effect on the microbead size. In addition, the flow rate affected microbead diameters in the similar manners for extrusion of either pure alginate solution (Figure 1) or 


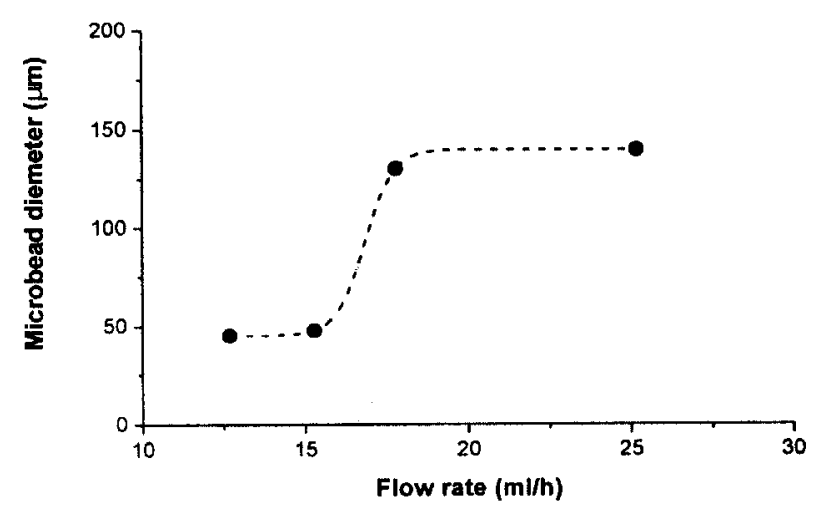

Figure 1. Effects of the alginate flow rate on the microbead diameter $(7.5 \mathrm{kV}$ applied potential, $2.5 \mathrm{~cm}$ electrode spacing, 22 gauge needle, $1 \% \mathrm{Na}$-alginate)

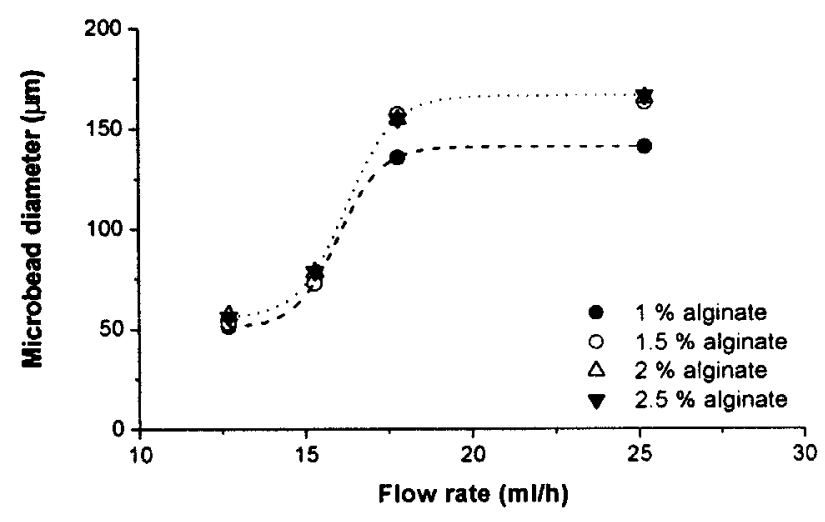

Figure 2. Effects of the polymer/cell suspension flow rate on the microbead diameter at different alginate concentrations $(7.5 \mathrm{kV}$ applied potential, $2.5 \mathrm{~cm}$ electrode spacing, 22 gauge needle, $4 \times 10^{7} \mathrm{cel} / \mathrm{s} / \mathrm{m} /$ of alginate)

cell/alginate suspensions (Figure 2). A decrease in flow rate from approximately 25 to $18 \mathrm{ml} / \mathrm{h}$ had negligible effect on microbead size. However, when the flow rate was further decreased to about $15 \mathrm{ml} / \mathrm{h}$ a $60 \%$ decrease in the bead diameter was observed. Further decrease of flow rate down to approximately $13 \mathrm{ml} / \mathrm{h}$ had no additional effect on the microbead size. The observed effects imply a change in droplet formation mechanism with the decrease of extrusion flow rate.

Results of the second experimental series are shown in Table 1. The increase in the alginate concentration from 1 to $2 \%$ had no effect on the average microbead diameter. However, when the alginate concentration was increased to $2.5 \%$ the microbead diameter increased by a factor of 2 . Still, the obtained microbeads were very small (below $200 \mu \mathrm{m}$ ). It should be mentioned that an earlier study demonstrated that the mean size of droplets increased by as much as four to five fold as the polymer viscosity was increased from $10^{3}$ and $10^{4} \mathrm{mPas}$ (Jayasing he and Edirisinge, 2004). In the present study, extrusion of alginate solutions was investigated over a narrow range of concentrations $(1 \%-2.5 \%)$ and, consequently, the observed effects were less pronounced. However, viscosities of the experimental alginate solutions will be determined in the next study in order to make a direct comparison.

Table 1. Effects of alginate concentration on the microbead size (13.9 $\mathrm{ml} / \mathrm{h}$ alginate flow rate)

\begin{tabular}{|c|c|}
\hline $\begin{array}{c}\text { Alginate concentration } \\
(\mathrm{w} / \mathrm{v})\end{array}$ & $\begin{array}{c}\text { Mean microbead diameter } \\
(\mu \mathrm{m})\end{array}$ \\
\hline $1 \%$ & 45.35 \\
\hline $1.5 \%$ & 46.14 \\
\hline $2 \%$ & 46.61 \\
\hline $2.5 \%$ & 103.71 \\
\hline
\end{tabular}

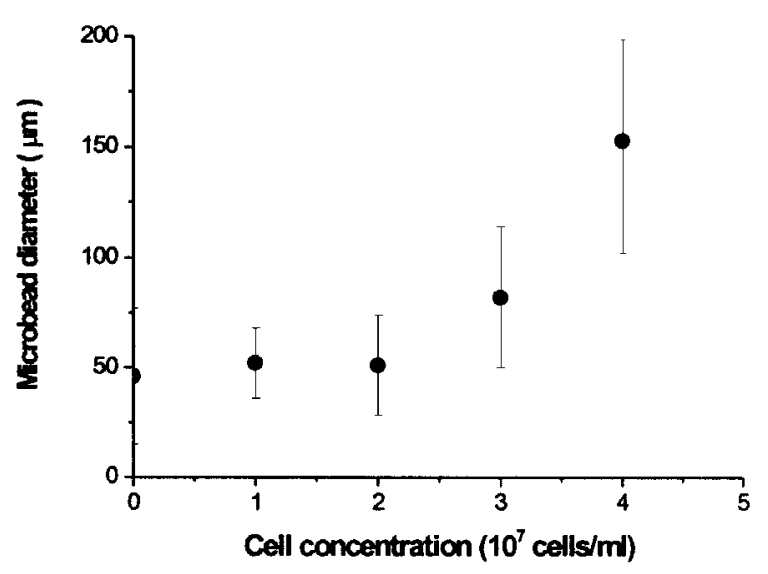

Figure 3. Effects of the initial cell concentration on the mean microbead diameter $(1.5 \%$ alginate concentration, $13.9 \mathrm{ml} / \mathrm{h}$ flow rate)

Effects of presence of cells in the polymer solution on microbead size were investigated at alginate concentrations in the range $1-2.5 \%$ and at cell concentrations in a rather narrow range of $1-4 \times 10^{7}$ cells $/ \mathrm{ml}$ of alginate. Results obtained with alginate concentration of $1.5 \%$ are presented in Figure 3 . It can be seen, that the presence of cells up to $2 \times 10^{7}$ cells $/ \mathrm{ml}$ had no effect on the microbead size. However, when the cell concentration was increased up to $4 \times 10^{7}$ cells $/ \mathrm{ml}$ the bead diameter increased by a factor of 3 . Still the produced microbeads were $<200 \mu \mathrm{m}$ in diameter.

\section{CONCLUSIONS}

Electrostatic droplet generation provides a means for controlled production of hydrogel microbeads with immobilized cells. For many different fermentation processes including beer, wine and cider fermentations, there is a distinctive demand for utilization of very small beads (< $1 \mathrm{~mm}$ in diameter) in order to avoid diffusion limitations of nutrients and metabolic products within the carrier matrix. Previous studies of this technique showed that the microbead diameter was reduced using higher voltages, smaller needle sizes and shorter electrode distances from the hardening solution. In this study, the 
effects of polymer flow rate and concentrations of alginate and cells on the microbead diameter were investigated. Among these parameters, the cell concentration may be a critical factor since it is often dictated by growth properties of the cell type or desired performance of the immobilized cell system. The presence of cells generally induces the increase in the microbead diameter. In the present study, it was demonstrated that low concentrations of brewing yeast cells up to $2 \times 10^{7}$ cells $/ \mathrm{ml}$ had no effect on the microbead size. However, further increase in cell concentration by only 2 -fold resulted in 3 times larger bead diameters indicating significant changes in flow and electric properties of cell/polymer suspension. On the other hand, the effects of polymer concentrations and flow rate observed in this study as well as the influences of other parameters investigated in previous studies, provide options for parameter optimization such that at each cell concentration, microbeads of targeted diameters at narrow size distributions could be produced. In the present study, at all investigated operating conditions of electrostatic droplet generation technique very small alginate microbeads were obtained $(<200 \mu \mathrm{m})$. Additional characterization and modeling studies at higher cell concentrations are required to elucidate the mechanisms of dorplet formation in two-phase (cell-polymer) flow under influence of the electric field.

\section{REFERENCES}

[1] Bugarski B. et al. (2004) Immobilization of cells and enzymes using electrostatic droplet generator. In: FOCUS ON BIOTECHNOLOGY, Volume 8a: Fundamentals of Cell Immobilisation Biotechnology, V. Nedovic and R.G. Willaert (eds.), Kluwer Academic Publishers, Dordrecht, pp. 261-278.

[2] Bugarski B. et al. (1994) Effect of the electrode geometry and charge on the production of polymer microbeads by electrostatics. Canad J Chem Engineer 72: 517-521

[3] Jayasinghe S.N., Edirisinge M.J (2004) Electrically forced jets and microthreads of high viscosity dielectric liquids. Aerosol Science 35: 233-243

[4] Nedovic V. et al. (2001) Electrostatic generation of alginate microbeads loaded with brewing yeast. Proc Biochem 37(1): 17-22

[5] Poncelet D. et al. (1999) Theory of electrostatic dispersion of polymer solutions in the production of microgel beads containing biocatalyst. Adv. Colloid Interface Sci. 79: 213-228. 